\title{
The history of Antarctic Peninsula glaciation
}

\author{
Peter F. Barker \\ Threshers Barn, Whitcott Keysett, Clun, SY7 8QE, UK (pfbarker@tiscali.co.uk)
}

\begin{abstract}
As Co-Chief Scientist on DSDP Leg 35 in 1974, Cam Craddock (1930-2006) produced the first useful information on Cenozoic Antarctic Peninsula glaciation - an early middle Miocene (15-17 Ma) apparent glacial onset. Subsequent work, onshore and offshore, has greatly extended our knowledge but that early conclusion stands today. Cenozoic Antarctic Peninsula palaeoclimate as presently known is broadly consistent with global palaeoclimate proxies. Initial glacial onset was within the Eocene-Oligocene boundary interval (although earlier, short-lived glaciations have been proposed, from indirect measurements) and the peninsula probably became deglaciated in the earliest Miocene (ca. $24 \mathrm{Ma}$ ). The renewed middle Miocene glaciation probably continued to the present and, for the last 9 Myr at least, has persisted through glacial (orbital) cycles, with grounded ice advance to the shelf edge during maxima. Although orbital cyclicity affected earlier AP palaeoclimate also, the level of glaciation through a complete cycle is uncertain.
\end{abstract}

Citation: Barker, P. F. (2007), The history of Antarctic Peninsula glaciation, in Antarctica: A Keystone in a Changing World - Online Proceedings of the 10th ISAES, edited by A.K. Cooper and C.R. Raymond et al., USGS Open-File Report 2007-1047, Short Research Paper 042, 5 p.; doi:10.3133/of2007-1047.srp042

\section{Introduction}

The Antarctic Peninsula (AP) is taken to be the western flank of the Weddell Sea, extending only as far west as about $80^{\circ} \mathrm{W}$ (Fig. 1), principally so as to avoid consideration of the effects of tectonically-induced vertical movement on climate, such as affect an understanding of West Antarctic glacial history within the zone of influence of the Marie Byrd Land/Ross Sea hotspot (e.g. LeMasurier and Rocchi, 2005). The AP is a long, narrow, northward extension of the continent, wider

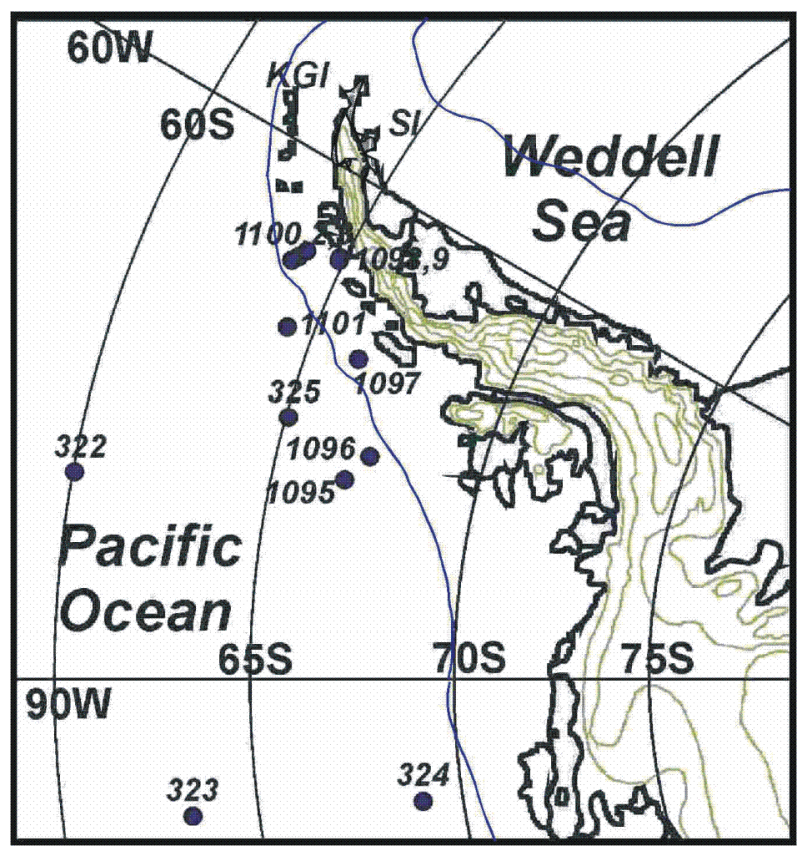

Figure 1. Present-day topography (including ice) on the Antarctic Peninsula (500m contour interval: after Drewry, 1983). 2000m bathymetric contour defines continental margin. KGI is King George Island; SI is Seymour Island. DSDP and ODP drill sites numbered.

in the south than in the north whether considering its elevated, seemingly peneplanated spine (about $2000 \mathrm{~m}$ high in the south, $900 \mathrm{~m}$ in the north), its land area or its fringeing continental shelves $(350 \mathrm{~km}$ wide in the north, including Bransfield Strait, $900 \mathrm{~km}$ wide in the southernmost Weddell Sea at about $72^{\circ} \mathrm{S}$ ). Pacific ocean floor has been subducted beneath it, but subduction has now almost completely ceased (earliest Cenozoic in the south, progressively farther north at a range of ages younging northward: Larter and Barker, 1991). Subduction probably continues opposite the South Shetland Islands in the farthest north. Sediment on this part of the Pacific ocean floor is largely AP-derived. The Weddell Sea margin was extensional (passive), and may all be Mesozoic in age. Most of the thick, mainly turbiditic sediments now flooring the Weddell Sea were derived from East and West Antarctica. Although the AP now has an elevated spine, such as might encourage precipitation and hence glaciation, there is no clear evidence, despite speculation (e.g. Elliot, 1997), that this elevation developed during the Cenozoic.

Barker and Camerlenghi (1999) described the late Pleistocene climatic regime of the AP as fully glacial, high-precipitation, high-relief, high-throughput and smallreservoir, leading to a rapid response to external change and an expanded offshore sedimentary record. This highprecipitation regime probably persisted through the Cenozoic, independently of the presence or absence of glaciation, as a result of the AP"s position at the Pacific margin. The AP is today warmer than East Antarctica (though both are fully glaciated), and there is a notable difference between mean annual temperatures on its (warmer) Pacific and (colder) Weddell Sea margins (Reynolds, 1981), which may result from clockwise circulation within the Weddell gyre of sea ice and icebergs formed farther south.

Evidence of glaciation may be termed direct or indirect. I regard both onshore geological and most of the proximal (Southern Ocean) marine geological evidence as direct, and the more-distal evidence (e.g. sea-level change, $\mathrm{Mg} / \mathrm{Ca}$ ratios, oxygen isotopes, carbonate 
compensation depth), and even some relatively proximal marine geological evidence such as changes in clay mineralogy of terrigenous sediments, as indirect. Essentially, direct evidence is unambiguous in itself, except for uncertainties in its age, whereas indirect evidence (generally remote from Antarctica) may have other explanations (even if not yet established), and has been used to infer palaeoclimate of the continent as a whole. I describe direct evidence only from the AP region. Given the different geographic locations and topography of East and West Antarctica, the Scotia Sea and the AP, it is unreasonable to conclude that direct evidence from these other regions can be used to indicate AP palaeoclimate.

In considering glaciation, "glacial onset" is taken to mean the initial advance of grounded ice to sea level. This seems the most useful definition, as it recognises the role of ice-rafted detritus (IRD) within the marine sediment record.

This paper describes the Cenozoic (post-Palaeocene) climatic history of the AP (excepting the current glacial cycle, a topic in its own right), including the earliest precise palaeoclimatic conclusions, produced in 1974 by DSDP Leg 35, on which Cam Craddock was Co-Chief Scientist. Subsequent work, onshore and offshore, has greatly extended our knowledge, but those early conclusions stand today.

\section{Exploration offshore and onshore}

DSDP Leg 35, drilling off the AP (Hollister, Craddock et al., 1976), found glacial dropstones of likely AP origin from the Pleistocene down to 15-17 Ma (early middle Miocene) at Site 325 (Fig. 1) within terrigenous sediments (turbidites?) typical of the continental rise, but not beneath. Drilling continued for a further 100-200m, but Eocene and probably Oligocene sediments were not sampled. The drill site was spot-cored, and sediments aged between 10 and $15 \mathrm{Ma}$ were missing, but every core obtained (down to 15-17 Ma) contained dropstones (IRD). Some 25 years later, ODP Leg 178 (Barker, Camerlenghi, Acton et al., 1999), drilling the till wedge on the outer continental shelf and fine-grained glacial drifts on the upper rise, showed AP glaciation back to at least $9 \mathrm{Ma}$, continuous through orbital cycles. The ice sheet reached the continental shelf edge during maxima (times of sealevel low-stand), seemingly independently of changes in ocean temperature (Barker and Camerlenghi, 2002). Seismic reflection profiles show clear differences between glacial and non-glacial sedimentation on both continental shelf and rise, and can therefore provide useful support for direct sampling, but are not themselves dateable. For example, the work of Rebesco et al (1997) on upper-rise sediment drifts supports the 15-17 Ma age for glacial onset produced by DSDP Leg 35 (Hollister, Craddock et al., 1976). However, there is no offshore evidence, either from drilling or from seismic reflection profiles, that indicates an earlier (Oligocene) glacial period, as is clearly shown by the onshore evidence (below). This is to be expected, given the preponderance of young ocean floor off the AP Pacific margin and the scarcity of drill sites.

Onshore evidence of Cenozoic climate is sparse, having been derived almost entirely from exposures on Seymour Island and King George Island, on the Weddell Sea and Pacific sides of the northernmost AP respectively (Fig. 1). Elsewhere, because of erosion, non-deposition or ice cover, the onshore Cenozoic record is almost everywhere absent. Offshore evidence (and most indirect evidence) comes from DSDP, ODP and IODP drilling, and is therefore also sparse, although for different reasons. In general, because of the scarcity of both, onshore and offshore direct evidence are complementary rather than mutually supportive or conflicting.

Seymour Island lies within the James Ross Island Group, raised above sea level over the past few million years by hotspot-related activity, and contains the only sediments within that group that concern us here. The Seymour Island succession comprises Campanian to Eocene shallow marine (shelf and deltaic) clastic sediments, including the Cenozoic Sobral, Cross Valley and La Meseta Formations, with abundant floras and faunas (e.g. Elliot, 1988). Many studies of Eocene and Palaeocene sediments have described cooling (but nonglacial) seawater temperatures and a diminishing diversity and abundance of flora and fauna (e.g. Askin, 1997; Hara, 1997; Reguero et al., 2002; Dutton et al., 2002). Ivany et al. (2006) reported thin, lowest Oligocene glacial marine sediments and lodgement till, directly above the Eocene La Meseta Fm., providing firmly-dated direct evidence of the earliest extension of glacier ice to sea level. Smellie et al (2006) have reported Late Neogene (the last 7 m.y. or so) interglacial events ("like today") from the James Ross Island group, consistent with the higher-resolution evidence of offshore drilling. Dingle and Lavelle (1998) reported a $9.9 \mathrm{Ma} \mathrm{Sr}$ isotopic date for glacigenic sediments on James Ross Island.

King George Island (KGI) is the largest and northernmost of the South Shetland Islands, now separated from the AP by the (probably Plio-Pleistocene) back-arc extensional Bransfield Strait (e.g. Barker, 1982) and thus earlier attached to the AP as part of its Pacific margin. It seems likely that the islands" present elevation is the result of this extension. The South Shetland Islands contain well-preserved Mesozoic and Cenozoic, mainly marine sediments with interbedded calc-alkaline lavas, pyroclastic rocks and dykes. The main exposures of Cenozoic sediments are on KGI.

Early work on KGI sediments, reported by Birkenmajer (1980 and subsequent papers) identified four glacial episodes ranging from early Eocene to Pliocene and two intervening interglacials, based on K-Ar dates on interbedded lavas (Birkenmajer et al., 1989) supported by zoning of fossils that were in some cases accompanied by reworked (and ice-rafted?) flora and fauna. Dingle and 
Lavelle (1998), Troedson and Riding (2002) and Troedson and Smellie (2002) revised these ages by Sr-isotope and ${ }^{39} \mathrm{Ar} /{ }^{40} \mathrm{Ar}$ dating, and reduced the glacial episodes to two, the older, "Polonez" episode within the late Oligocene. The discontinuous nature of the exposed sedimentary sections hampered correlation and made such revisions possible.

The presence of exotic clasts within glacial sediments, of rocks now known only from outcrop close to the southernmost Weddell Sea, was explained by Troedson and Smellie (2002) by rafting of debris-laden ice from farther south, around a clockwise Weddell gyre and through shallow-water (shelf) connections into the Pacific, as today, rather than by direct transfer within a much larger ice sheet as originally proposed. Troedson and Riding (2002) identified an earliest Miocene (22-23 Ma) "Melville" glacial episode (correlated with the short-lived Mi-1 event, that was followed by warming and possible deglaciation) and a latest Oligocene (26-24 Ma) interglacial period. Many features of the glacigenic sediments described indicate a sub-polar to polar glaciation, with warmer seawater than today, a greater role for meltwater and smaller or absent ice-shelves etc. The younger sediments suggest glacial retreat. Birkenmajer and Zastawniak (1989) reported early Oligocene/late Eocene and Oligocene/Miocene flora from presumed interglacials, but both more-precise ages and inter-relationships between isolated exposures remain to be established. Each section shows at most one glacial/interglacial cycle, so it is possible that the rock record is discontinuous in time, and represents only a small number of orbital ("Milankovich") cycles within the late Oligocene and early Miocene. Vanneste and Larter (1995) reported sediment thicknesses on the AP shelf from the last glacial episode comparable with those reported from KGI which, despite clear differences in environments of deposition, supports this view.

Thorn and De Conto (2006) have compared the palaeoclimate inferred from the KGI faunal assemblages with a numerical climate model, inferring a 3 times preindustrial $\mathrm{CO}_{2}$ level. They found the Antarctic Peninsula palaeoclimate warmer than that of the Ross Sea region (assumed to represent Antarctica in general), and

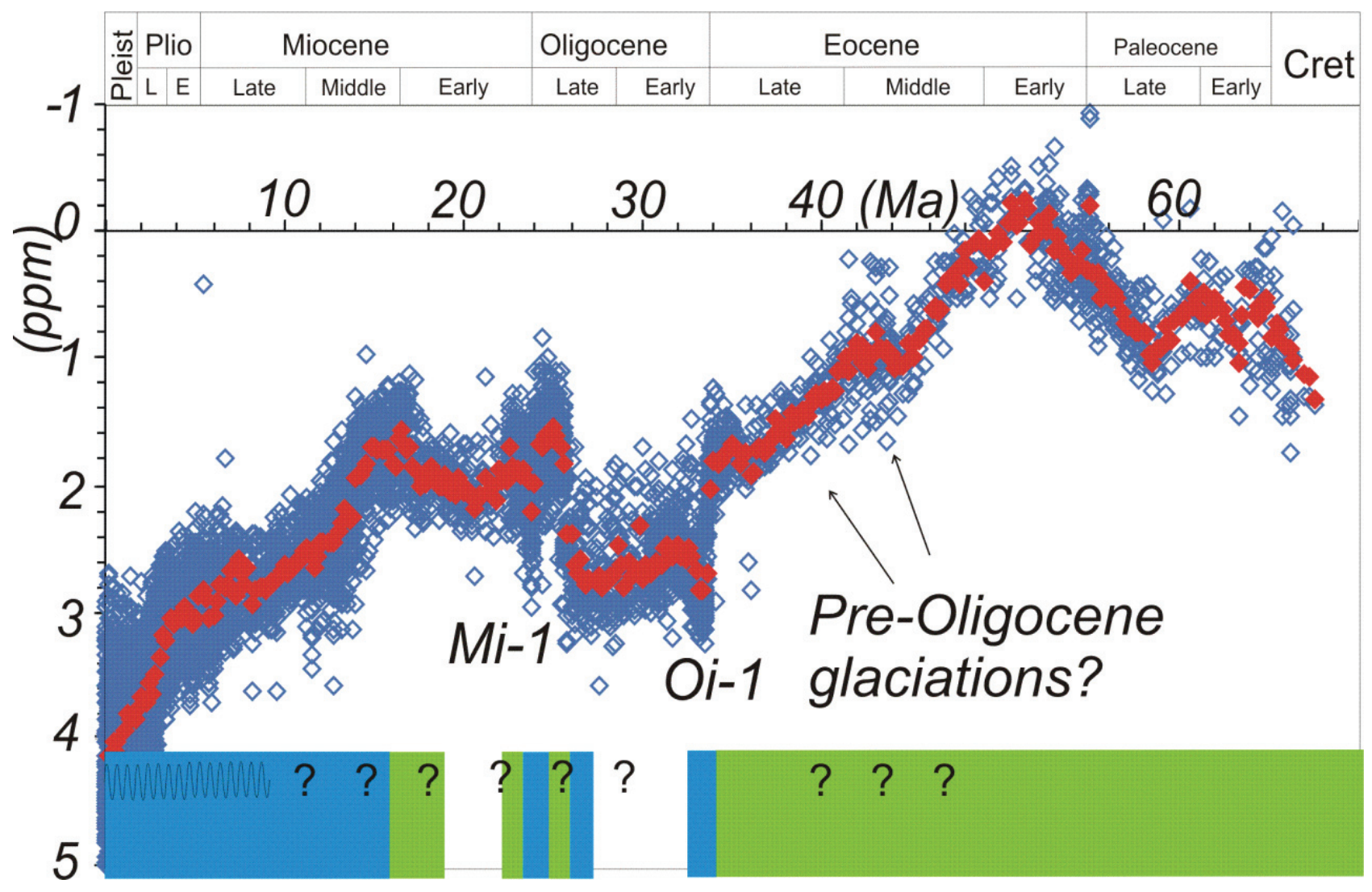

Figure 2. Compilation of oxygen isotopic ratios from benthic foraminifera (Zachos et al., 2001) for the Cenozoic, compared with direct geological determinations of Antarctic Peninsula palaeoclimate. Open diamonds are raw isotopic data, red points are 0.2 myr averages. For the AP, green is non-glacial, blue is glacial, sine wave shows schematically the time extent of established orbital cyclicity, queries mark principal unknowns. For further information, see text. 
suggested a positive feedback role for the transition from forest to tundra vegetation.

The onset time of AP glaciation has remained uncertain. It is now well-established that stable Antarctic glaciation developed quickly, within the EoceneOligocene boundary $(\mathrm{E} / \mathrm{O})$ interval, but the involvement in this of the AP, given its northerly position relative to East Antarctica (even taking into account Polar Wander, e.g. DiVenere et al., 1994), cannot be assumed. Numerical models of ice-sheet growth (Huybrechts, 1993; De Conto and Pollard, 2003) imply later AP glaciation, as expected, but suggest also rapid glacial onset because of a nonlinear ice-sheet response to climate change, so that the delay between East Antarctic and AP glaciation could be so short as to be undetectable. Indirect measurements (for example, the compilation of oxygen isotopic ratios from benthic foraminifera by Zachos et al., 2001; Fig. 2) also suggest rapid onset within the E/O interval. The evidence of Ivany et al. (2006) supports this view. Hitherto, the oldest clear evidence of AP glaciation was of middle to late Oligocene age from glacial sediments on KGI (Troedson and Smellie, 2002).

Other indirect measurements (e.g. of $\mathrm{CaCO}_{3}$ and oxygen isotopes from ODP Leg 199 sites in the Equatorial Pacific - Tripati et al., 2005) have been used to propose even earlier (middle and late Eocene) glaciations that were short-lived, and for which the AP involvement is uncertain. More-direct evidence, a 45-41 Ma K-Ar age for mountain glaciation on KGI (Birkenmajer et al., 2005), cannot be considered clear support for this at present, because of the earlier re-dating (by Sr-isotopes and ${ }^{39} \mathrm{Ar} /{ }^{40} \mathrm{Ar}$ ) of previously-reported early K-Ar-constrained glaciations in the same region (Birkenmajer et al., 1987; Dingle and Lavelle, 1998; Troedson and Smellie, 2002). As yet, no firm direct evidence (e.g. IRD) of Eocene AP glaciation has been found.

\section{Discussion - future work}

Onshore and offshore determinations of AP Cenozoic palaeoclimate are complementary, a reflection mainly of the sparse nature of each. The direct record of AP palaeoclimate through the Cenozoic is incomplete, but seems compatible with the record of global palaeoclimate provided by oxygen isotopic data (Fig. 2). AP glaciation appears to coincide, in general terms, with global cool periods, and non-glacial episodes with global warmth.

It is clear that the present record of Cenozoic AP climate has many gaps and omissions that can be addressed by future research, more valuably than seeking onshore confirmation of offshore results or vice versa. One important effort is that of the US "SHALDRIL", currently targeted at the continental shelf off Seymour Island, where younger sediments than are exposed onshore may be accessible. In particular, it would be useful to look for evidence of possible mid-Miocene deglaciation, to check the conclusions of Ivany et al., (2006) regarding the onset of stable glaciation of the AP, and to test the hypothesis of short-lived Eocene glaciations (as may also be attempted onshore).

In more detail, the orbital ("glacial-interglacial") variations in global insolation seem likely to have influenced AP palaeoclimate throughout the Cenozoic. Orbital cyclicity was a feature of the past 9-10 million years of AP glaciation in sediments sampled during ODP Leg 178 (Barker and Camerlenghi, 2002), and there seems little doubt that it will have affected earlier AP climate also. In particular, the sparse post-Eocene onshore record probably relates to a small number of individual halfcycles, making it of shorter extent than generally acknowledged. Cape Roberts drilling, in the Ross Sea, recorded more than 20 Oligocene-early Miocene glacial cycles (Cape Roberts Science Team, 1999).

There is an additional, likely but unfortunate consequence of glacial cyclicity, bearing in mind that glacial sediments may have been deposited around glacial maxima, at times when, around minima, there was little AP ice, or they may have been deposited (as found for the late Miocene onwards by ODP Leg 178) during a period of persistent, deep glaciation. In both cases, the level of erosion during "glacial" half-cycles would have been deeper, leading to the preferential preservation of the "glacial" sedimentary record, so that the level of glaciation through a complete cycle (ie fully glacial or glacial/nonglacial) remains uncertain. It therefore becomes particularly important to seek evidence of the nature and extent of warm periods, for which the deep-sea record becomes the more useful because of non-preservation onshore and on continental margins. Returning to the longer-term history, the glaciological model of Huybrechts (1993) suggests that further cooling beneath a threshold level, well below the present level for Antarctica as a whole, would not greatly modify ice sheet volume, but a latest time for interglacial deglaciation, within the middle Miocene perhaps, would be a useful future target.

\section{Summary}

AP climatic history is not yet fully and securely known, but what has been established forms an interesting and consistent story, that appears to be compatible with the isotopic record of global marine palaeotemperature and ice volume (Fig. 2).

1. The present-day glacial state, in which the AP is glaciated continuously, through times of maximal global insolation ("glacial minima"), as well as glacial maxima, extended back to at least 9-10 Ma - ODP Leg 178

2. Likely glaciation of some kind (the climate during "interglacials" is unknown) from 15-17 Ma to 9-10 Ma was preceded by a non-glacial period - DSDP Leg 35.

3. Glaciation of some kind occurred in the earliest Miocene (22-23 Ma), and was preceded by a non-glacial period (24-26 Ma) and glaciation in the late Oligocene (26-30 Ma) - KGI. The onshore rock record may represent much shorter periods.

4. Glacial onset (grounded ice reaching sea level) 
occurred within the E/O interval (33.5-35 Ma?) - Seymour Island

5. Palaeocene and Eocene climates showed a cooling trend but appear non-glacial - Seymour Island. Firm direct evidence has not been found of the short-lived middle and late Eocene glaciations hypothesised on the basis of indirect evidence.

Apart from the first of these conclusions, the climatic state of the AP through an orbital cycle and the time extents represented by the examined sediments are unknown. Future work, probably more usefully concentrated on the offshore record, should seek evidence of the nature and extent of warm periods and test the hypothesis of short-lived Eocene glaciations.

Acknowledgments. I am grateful to Wes LeMasurier for organising an opportunity to acknowledge Cam Craddock s many contributions to Antarctic Earth Science, to Wes LeMasurier and Alan Cooper for editorial efforts and advice, and to Rob Larter and Larry Lawver for many helpful comments.

\section{References}

Askin, R.A., 1997. Eocene-?earliest Oligocene terrestrial palynology of Seymour Island, Antarctica. In C.A. Ricci (Ed) The Antarctic Region: Geological Evolution and Processes., 993-996.

Barker, P.F., 1982. The Cenozoic subduction history of the Pacific margin of the Antarctic Peninsula: ridge crest trench interactions. Geol. Soc. London J., 139:787-801.

Barker, P.F., Camerlenghi, A., 1999. An approach to Antarctic glacial history: the aims of Leg 178. In Barker, P.F., Camerlenghi, A., Acton, G.D., et al., 1999. Proc. ODP, Init. Repts., 178, 1-44 [CD-ROM]. Available from: Ocean Drilling Program, College Station, TX 778459547, U.S.A.

Barker, P.F., Camerlenghi, A., 2002. Glacial history of the Antarctic Peninsula from Pacific margin sediments. In Barker, P.F., Camerlenghi, A., Acton, G.D., Ramsay, A.T.S. (Eds.). Proc. ODP, Sci Results, 178: College Station TX (Ocean Drilling Program), 1-40.

Barker, P.F., Camerlenghi, A., Acton, G.D., et al., 1999. Proc. ODP, Init. Repts., 178 [CD-ROM]. Available from: Ocean Drilling Program, College Station, TX 77845-9547, U.S.A.

Birkenmajer, K., 1980. Discovery of Pliocene glaciation on King George Island, South Shetland Islands (West Antarctica). Acad. Pol. Sci. Bull., Ser. Sci. de la Terre, 27, 59-67.

Birkenmajer, K., Zastawniak E., 1989. Late Cretaceous-Early Tertiary floras of King George Island, West Antarctica: their stratigraphic distribution and palaeoclimatic significance. In Origins and Evolution of the Antarctic Biota. Sp. Publ. Geol. Soc. Lond. 147, 227-240.

Birkenmajer, K., Soliani, E., Kawashita, K., 1989. Geochronology of Tertiary glaciations on King George Island, West Antarctica. Bull. Pol. Acad. Sci., Earth Sci., 37, 27-48.

Birkenmajer, K., Gazdzicki, A., Krajewski, K.P., Przybycin, Solecki, A., Tatur, A., Yoon, H.I., 2005. First Cenozoic glaciers in West Antarctica. Polish Polar Research, 26, 3-12.

Cape Roberts Science Team, 2000. Studies from the Cape Roberts Project, Ross Sea, Antarctica. Initial Report on CRP-2/2a, Terra Antartica,. 6: 1-173.

Dingle, R.V., Lavelle, M., 1998. Antarctic Peninsular cryosphere: early Oligocene (c. $30 \mathrm{Ma}$ ) initiation and revised glacial chronology. J. Geol. Soc., 155: 433-7.

DiVenere, V.J., Kent, D.V., Dalziel, I.W.D., 1994. Mid-Cretaceous palaeomagnetic results from Marie Byrd Land, West Antarctica: a test of post-100 Ma relative motion between East and West Antarctica. J. geophys. Res., 99: 15115-15139.

Drewry D.J., 1983. Antarctica: Glaciological and Geophysical Folio. Scott Polar Res. Inst., Cambridge England, 9 sheets.

Dutton, A.L., Lohmann, K.C., Zinsmeister, W.J., 2002. Stable isotope and minor element proxies for Eocene climate of Seymour Island, Antarctica. Palaeoceanography, 17, 10.1029/2000PA00593.

Elliot, D.H., 1988. Tectonic setting and evolution of the James Ross Basin, northern Antarctic Peninsula. In Feldmann R.M., Woodburne M.O. (Eds.) Geology and Palaeontology of Seymour Island, Antarctic Peninsula. Mem. Geol. Soc. Amer., 169, 541-555.

Elliot, D.H., 1997. The planar crest of Graham Land, northern Antarctic Peninsula: possible origins and timing of uplift. In Barker, P. F. And Cooper, A. K. (Eds.), Geology and Seismic Stratigraphy of the Antarctic Margin, Part 2, AGU Antarctic Research Series 71, 51-73.

Hara, U., 1997. Bryozoan assemblages from the La Meseta Formation (Eocene) of Seymour Island, Antarctic Peninsula. In C.A. Ricci (Ed) The Antarctic Region: Geological Evolution and Processes., 10011006.

Hollister, C. D., Craddock, C., et al., 1976 Initial Reports of the Deep Sea Drilling Project Volume 35. U.S. Government Printing Office, Washington, 930pp.

Huybrechts P., 1993. Glaciological modelling of the Late Cenozoic East Antarctic ice sheet: stability or dynamism, Geografiska Annaler, 75A, 221-238.

Ivany, L.C., Van Simaeys, S., Domack, E.W., Samson, S.D., 2006. Evidence for an earliest Oligocene ice sheet on the Antarctic Peninsula. Geology, 34, 377-380.

Larter, R.D., Barker, P.F., 1991. Effects of ridge_crest trench interaction on Antarctic Phoenix spreading: forces on a young subducting plate. J.Geophys. Res., 96:19,583-19,607.

Le Masurier, W.E., Rocchi, S., 2005. Terrestrial record of post-Eocene climate history in Marie Byrd Land, West Antarctica. Geografisker Annaler. 87A (1): 51-66.

Rebesco, M., Larter, R. D., Barker, P. F., Camerlenghi, A., Vanneste, L. E., 1997. The history of sedimentation on the continental rise west of the Antarctic Peninsula. In Barker, P. F. And Cooper, A. K. (Eds.), Geology and Seismic Stratigraphy of the Antarctic Margin, Part 2, AGU Antarctic Research Series 71, 29-49.

Reguero, M.A., Marenssi, S.A., Santillana, S.N., 2002. Antarctic Peninsula and South America (Patagonia) Palaeogene terrestrial faunas and environments: biogeographic relationships. Palaeogeogr., Palaeoclim., Palaeoecol., 179: 189-210.

Reynolds, J.M., 1981. The distribution of mean annual temperatures in the Antarctic Peninsula. Br. Antarct. Surv. Bull., 54, 123-133.

Smellie, J.L., McArthur, J.M., McIntosh, W.C., Esser, R., 2006. Late Neogene interglacial events in the northern Antarctic Peninsula, dated by $\mathrm{Ar} / \mathrm{Ar}$ and Sr-isotope stratigraphy. Palaeogeogr., Palaeoclim., Palaeoecol., 242, 169-187.

Thorn, V., De Conto, R., 2006. Antarctic climate at the Eocene/Oligocene boundary-climate model sensitivity to high latitude vegetation type and comparison with the palaeobotanical record. Palaeogeogr., Palaeoclim., Palaeoecol., 231, 134-157.

Tripati, A., Backman, J., Elderfield, H., Ferretti, P., 2005. Eocene bipolar glaciation associated with global carbon cycle changes. Nature, 436 : 341-346.

Troedson, A.L., Riding, J.B., 2002. Late Oligocene to earliest Miocene strata of King George Island, South Shetland Islands, Antarctica: stratigraphy, facies analysis and implications for Antarctic Peninsula glacial history. J. Sed. Res., 72, 510-523.

Troedson, A.L., Smellie, J.L., 2002. The Polonez Cove Formation of King George Island, West Antarctica; stratigraphy, facies and palaeoenvironmental implications. Sedimentology, 49: 277-301.

Vanneste, L.E., and Larter, R.D., 1995. Deep-tow boomer survey on the Antarctic Peninsula Pacific margin: an investigation of the morphology and acoustic characteristics of Late Quaternary sedimentary deposits on the outer continental shelf and upper slope. In Cooper, A.K., Barker, P.F., and Brancolini, G., (Eds.), Geology and Seismic Stratigraphy of the Antarctic Margin. Antarct. Res. Ser., 68, AGU Washington, DC. 97-121.

Zachos, J.C., Pagani, M., Sloan, L., Thomas, E., Billups, K., 2001. Trends, rhythms and aberrations in global climate, 65 Ma to present. Science, 292: 686-693. 